\title{
Environmental Threats of Natural Water Contamination with Polybrominated Diphenyl Ethers (PBDEs)
}

\author{
Bogumila Winid* \\ Faculty of Drilling, Oil and Gas, AGH University of Science and Technology, \\ Mickiewicza 30, 30-059 Cracow, Poland \\ Received: 13 June 2014 \\ Accepted: 8 July 2014
}

\begin{abstract}
Polybrominated diphenyl ethers (PBDEs) are a class of synthetic halogenated organic compounds used in numerous polymer-based commercial and household products such as textiles, furniture, and electronics, to increase their flame ignition resistance and to meet increasingly strict fire safety standards. Release of PBDEs to the environment can occur during manufacturing and processing operations, throughout the service life of articles containing PBDEs, and when articles that contain PBDEs are disposed of. Within highly populated areas, elevated concentrations in air, water, sediment, and soil are associated with proximity to manufacturing, recycling, and waste disposal facilities, signifying that these may serve as point sources of PBDEs in abiotic media. Polybrominated diphenyl ethers (PBDEs) can be transported in the environment for long distances from their primary sources and pose a risk to human health and the environment. There is increasing regulation and phasing-out of production of PBDEs due to their widespread presence in the environment and potentially deleterious effects on ecosystems and human health. According to the regulations of the Minister of the Environment in Poland, PBDEs are in the group of priority substances for which environmental quality standards have been established. In many cases the determination was not performed due to the lack of standardized methods. The main issue addressed in this paper - the potential occurrence of PBDEs in waters in the hypergene zone - was investigated based on available information about PBDE levels in surface waters, soils, and sediments. Levels of PBDEs in aquatic environments presented in the article and based on the review of the cited paper, reveal that the threat of PBDEs in Poland could be real. However, the current expertise in this field is still too limited to allow a reliable assessment of the scale of the problem.
\end{abstract}

Keywords: PBDE, brominated flame retardants, environmental occurrence, water contamination

\section{Introduction}

The natural environment has become the recipient of persistent organic pollutants. The types of pollutants and wastes vary with industrialization levels. As a consequence of extensive environmental studies following the degrada-

*e-mail: winid@agh.edu.pl 
ments in monitoring long-term trends in their concentrations [2]. Reports on PBDE determination in waters are rather scarce, mainly due to the lack of standardized methods [3]. However, the growing concern about the PBDE presence in all levels of the ecosystem in recent years has resulted in an increased number of publications on the subject. A great deal of attention is given to PBDE concentrations in living organisms (including those living in waters). PBDE levels are determined in more and less polluted waters, in surface waters (rivers and lakes), and in landfill leachate or effluents from wastewater treatment plants. The quality assessment of the aquatic environment can be supported by determination of PBDE in soils and sediments. PBDEs concentrations in groundwaters has received little attention so far, yet it is reasonable to suppose that their role as the quality indicator will be duly appreciated in the future. This study summarizes the factors responsible for PBDE occurrence and provides the ranges of PBDE concentrations determined in the abiotic land and water environment. The main issue addressed in this paper - the potential occurrence of PBDEs in waters in the hypergene zone - is investigated based on available information about PBDE levels in surface waters, soils, and sediments. Due to the scarcity of PBDE determination data from Poland, the results were also taken from available reports. The uncertainty levels of the analyzed PBDE determinations would differ and were not always specified. The total PBDE concentration in waters and wastewater (in the dissolved and suspended phase) is expressed in ng/L. The concentrations in soils and sediments is given in $n g / g$ of dry mass.

\section{Description and Applications of PBDE}

PBDEs are organic compounds, derivatives of diphenyl ethers in which 1 to 10 atoms of hydrogen in aromatic rings are substituted by bromine. Theoretically, 206 PBDE congeners are possible [3]. These compounds have a high temperature of ignition, hence they are widely used as inhibitors of combustion. They belong to the group of additive antypirenes since they are retained in polymer through physical interactions rather than by chemical bonds and therefore are easily released to the environment. PBDEs are persistent and lipophilic compounds while present in the ecosystem, and they tend to bioaccumulate in fat tissues of animals and humans. Under the Stockholm Convention [4] they are listed as persistent organic pollutants. PBDEs display a variety of physico-chemical and toxic properties. Since they were categorized as potential carcinogens and endocrine disruptors, their presence is the environment is perceived as a major threat [5]. The stability of PBDEs is associated with the bromine substitution. Lighter PBDEs tend to be more stable. Transformations of PBDEs congeners are triggered by natural factors, both physical and chemical, and thus formed products may prove to be even more toxic. Debromination gives rise to the formation of PBDEs, whose molecules contain a smaller number of bromide atoms and polibrominated dibenzen furans, brominated phenols, and bromobenzenes.
PBDEs have been manufactured since 1965 [5] and used as additives to chemically harden plastics and in manufacturing of office equipment (telephones, copying machines, electric devices and electronics (computers, TV sets, household goods, domestic appliances). They also find use in manufacturing of polyurethane foam widely used in industries. Three dominant commercial mixtures of these compounds are: penta- octa- and deca- mixes of congeners differing in the number of bromine atoms in the molecule. In the early $21^{\text {st }}$ century the world production of PBDEs would approach 67,000 tons (penta-PBDE - 7,500 tons, octa PBDE - 3,790 tons and deca-PBDE - 56,100 tons). The US would account for $49 \%$ of the use of PBDEs, in Asia the figure is $37 \%$, and in Europe $12 \%$. The environmental impacts are still significant since used and scrapped electronic devices are often exported to developing countries to be dumped or dismantled and recycled $[3,6]$.

The use of PBDEs is Poland has been restricted since 2004, when a regulation came into force banning the use of certain substances produced in the electronics sector and potentially harmful to the environment, in accordance with WE Directive 2002/95 implemented at that time. Under this regulation and under the new Regulation of 8 May 2013 [7] the maximal admissible concentration of PBDEs in homogeneous materials measured by weight is $0.1 \%$. The use of deca-PBDEs was restricted in 2008. These restrictions differ between countries, for example in China the use of deca-PBDEs is not regulated in any way [8]. Restrictions relating to quality of commercial products led to the reduction of the amounts of PBDEs, though products containing those substances are still present in the environment.

\section{PBDE Occurrence in the Environment}

\section{Atmospheric Emissions}

PBDEs do not occur naturally; their presence was not registered in deep rock strata [6]. Manufacturing processes, decomposition of products containing PBDEs, and dismantling and recycling of scrapped electronic devices are the main source of PBDE emissions throughout the entire lifecycle of these products. PBDE congeners predominant in the environment are: BDE-47, BDE-99, BDE-183, BDE209 and their mixes. Plastic products may contain up to $32 \%$ PBDEs by weight [9]. The proportion of PBDEs in scrapped electronic devices range from several ppm to several percent, depending on the product type and particular brand. In California (USA) the average PBDE content is $2,400 \mathrm{mg} / \mathrm{kg}$ [10]. It is estimated that the recycling of electric and electronic equipment in China is the source of emissions of $224,000 \mathrm{~kg}$ deca-PBDE and 233,000 kg of octa-PBDE to the atmosphere per year. Dumping of electric and electronic equipment produces 157,000 of deca-PBDE per year and $163,000 \mathrm{~kg}$ of octa-PBDE per year, the combustion processes contribute of $13 \mathrm{~kg}$ and $14 \mathrm{~kg}$ each per year [8]. Differences in PBDE concentrations in the atmosphere are a consequence of the presence of local sources and the range 
Table 1. PBDEs in outdoor air samples.

\begin{tabular}{|c|c|c|c|c|}
\hline Area & PBDE & Range(median) $\left[\mathrm{pg} / \mathrm{m}^{3}\right]$ & Country/region & Reference \\
\hline Baltic Sea & $\sum \mathrm{PBDE}$ & (8.6) & $\begin{array}{l}\text { Sweden, Gotska } \\
\text { Sandom Island }\end{array}$ & {$[11]$} \\
\hline \multirow{4}{*}{ Artic region, offshore } & $\sum \mathrm{PBDE}$ & $0.78-48(6.2)$ & \multirow{4}{*}{$\begin{array}{c}\text { Canada, Alert, } \\
\text { Nunavut }\end{array}$} & \multirow{4}{*}[12]{} \\
\hline & BDE-47 & $0.21-18(1.4)$ & & \\
\hline & BDE-99 & $0.19-22(1.30)$ & & \\
\hline & BDE-209 & $0.091-9.8(0.89)$ & & \\
\hline Rural site & $\sum$ PBDE (without 209) & $2.84 \pm 4.23$ & UK, West Midlands & [13] \\
\hline \multirow{2}{*}{ Peri-Alpine lake } & $\sum \mathrm{PBDE}$ & $26.3-405.5$ & \multirow{2}{*}{ Switzerland Tun Lake } & \multirow{2}{*}[14]{} \\
\hline & BDE-47 & $22.9-405.5$ & & \\
\hline Urban site & $\sum \mathrm{PBDE}$ & $16.2-100$ & USA & {$[15]$} \\
\hline \multirow{2}{*}{ Urban site } & $\sum \mathrm{PBDE}$ & $40.5 \pm 33.5-202 \pm 213.2$ & \multirow{4}{*}{ Northern China } & \multirow{4}{*}[16]{} \\
\hline & BDE-209 & $27.3 \pm 38.3-171.2 \pm 211.9$ & & \\
\hline \multirow{2}{*}{ Rural-field site } & $\sum \mathrm{PBDE}$ & $22 \pm 20.6-57.2 \pm 4.8$ & & \\
\hline & BDE-209 & $11.9 \pm 14.6-32 \pm 20.6$ & & \\
\hline Vicinity of a wastewater treatment plant & $\sum \mathrm{PBDE}$ & $34.0-95.9$ & Italy & {$[17]$} \\
\hline \multirow{2}{*}{ Vicinity of the electronics recycling plants } & $\sum \mathrm{PBDE}$ & $884-2791$ & China, Taizhou & {$[18]$} \\
\hline & $\sum \mathrm{PBDE}$ & $5397-47187$ & China, Guiyi & [19] \\
\hline
\end{tabular}

of atmospheric transport of pollutants. PBDE concentrations in areas distant from local sources of pollutants are of the order of several $\mathrm{pg} / \mathrm{m}^{3}$. The highest concentrations were registered in the neighbourhood of the electronics recycling plants. Selected atmospheric PBDE concentrations in areas differing in the land development and industrialization levels are summarized in Table 1.

\section{Atmospheric Deposition}

Atmospheric PBDEs return to the ground in the form of dry and wet deposition. Measurements taken in Europe show the atmospheric deposition of about $10 \mathrm{ng} / \mathrm{m} 2$ per day. Select examples of atmospheric deposition of PBDEs world-wide are summarized in Table 2.

\section{Landfills and Dumping Sites}

PBDE concentration levels determined in landfill leachate vary by several orders of magnitude (Fig. 1). The concentration is found to increase with the industrialization level and population figures [25]. The PBDE congener profile is diverse too, which is associated with the waste type and the dumping strategy. Relatively low levels registered in Japan may be attributable to the incineration of nearly $80 \%$ of municipal waste. PBDE contents in leachate approached $4 \mathrm{ng} / \mathrm{L}$ [26]. Fig. 1 shows the concentrations of widely detected congeners in dumping sites in various countries. The points given correspond to maximum levels.

\section{Wastewater Treatment Plants}

Many organic pollutants are present in municipal wastewater [27]. PBDEs determinable by available methods are present in influents and effluents from the treatment plants (Fig. 1). Significant amounts of PBDEs are registered in the summertime and when there is more industrial than municipal waste [28]. The preliminary treatment can cause their

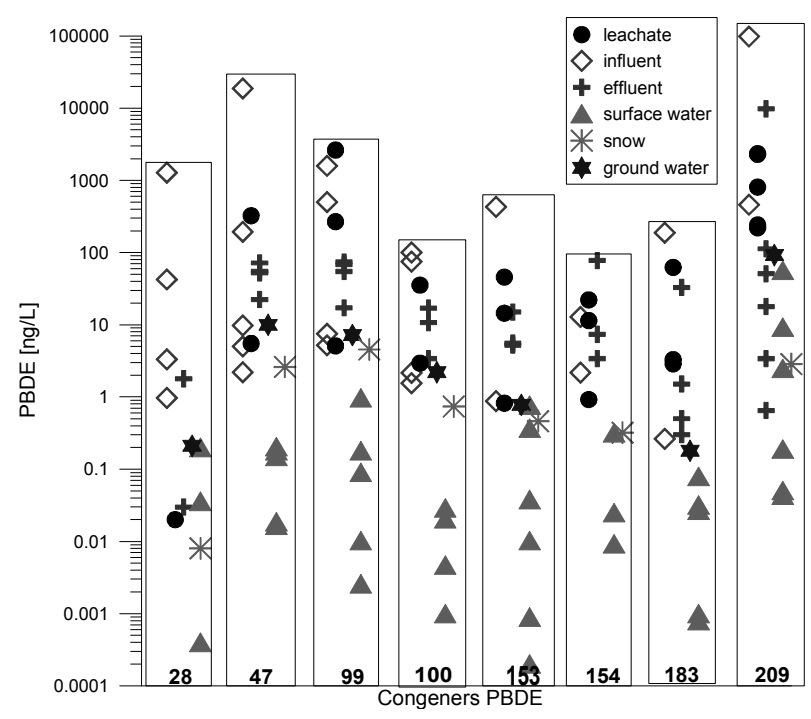

Fig. 1. PBDEs in waters differing in the level of pollution-landfill leachate [25, 31-33] influents [17, 28, 33-35], effluents [28, $33,35-37]$ surface waters [14, 35, 38-40], snow [21], and ground waters [41]. 
Table 2. PBDEs in atmospheric deposition.

\begin{tabular}{|c|c|c|c|c|}
\hline Area & PBDE & Range ng/m² per day & Country, region & Reference \\
\hline Campus & $\sum \mathrm{BDE}$ & $2 \pm 1$ & Sweden, Lund & [11] \\
\hline \multirow{2}{*}{ Alps Monte Rosa Massif } & $\sum \mathrm{BDE}$ & 1.38 & \multirow{2}{*}{ Swiss-Italian border } & \multirow{2}{*}[21]{} \\
\hline & BDE-209 & 0.5 & & \\
\hline \multirow{2}{*}{ Vicinity of Lake Maggiore } & $\sum \mathrm{BDE}$ & 17.61 & \multirow{2}{*}{ Italy } & \multirow{2}{*}[22]{} \\
\hline & BDE-209 & 8.5 & & \\
\hline \multirow{2}{*}{ Rural site } & $\sum \mathrm{BDE}$ & $27.67-64.6$ & \multirow{4}{*}{ South Korea } & \multirow{4}{*}[23]{} \\
\hline & BDE-209 & $25.44-60.67$ & & \\
\hline \multirow{2}{*}{ Urban site } & $\sum \mathrm{BDE}$ & $63.0-243.83$ & & \\
\hline & BDE-209 & $61.23-235.22$ & & \\
\hline Rural site & $\sum \mathrm{BDE}$ & $13.44-41.49$ & \multirow{4}{*}{ Taiwan } & \multirow{4}{*}[24]{} \\
\hline 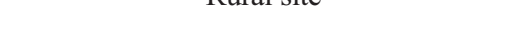 & BDE-209 & $10.30-34.74$ & & \\
\hline \multirow{2}{*}{ Urban site } & $\sum \mathrm{BDE}$ & $32.95-60.42$ & & \\
\hline & BDE-209 & $26.03-52.34$ & & \\
\hline Vicinity of the electronics recycling plants & $\sum \mathrm{BDE}$ & $3,835.62-11,780.82$ & China, Taizhou & [18] \\
\hline
\end{tabular}

amount to be reduced by $70 \%$ [28] and in the case of more advanced treatment strategies by $90-98 \%$ [29, 30]. Better performance is achieved when combined biological and chemical treatments are employed, biological methods produce slightly poorer results [30]. The major determinant of PBDE reduction efficiency is sorption of sewage sludge. The efficiency of PBDE removal is correlated with the level of reduction of conventional parameters of polluted waters: biological oxygen demand and the sum of solid components [28]. Similar to sewage sludge, PBDE levels in sewage water (Fig. 1) vary by several orders of magnitude (Fig. 2).

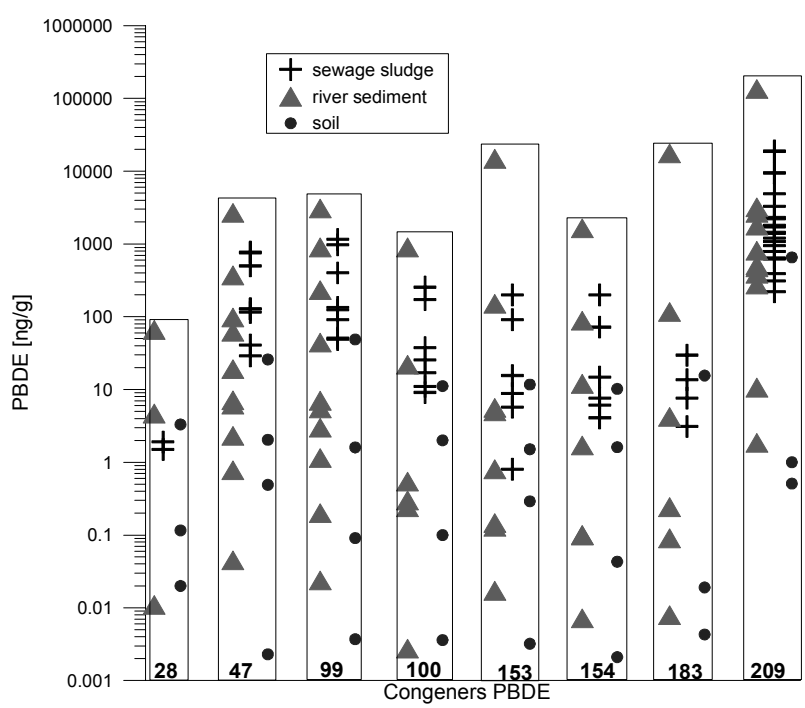

Fig. 2. PBDEs in sewage sludge [34, 42-48], river sediments [39, 47, 49-53], and soil [after 13, 45, 54, 55].

\section{PBDEs in Soils and Aquatic Environments}

\section{Surface and Ground Waters}

PBDE concentrations are relatively low compared to inorganic micro-components. Points indicated in Fig. 1 correspond to the maximal determined concentrations. Apart from waters in lakes and rivers, results are given that were determined in firn core from Colle Gnifetti in the Monte Rosa Massif in the Swiss-Italian Alps [21]. The maximal concentration levels registered over the years 1996-2008 do not exceed several ng/L, though they are not lower than in rivers. In the peri-alpine Thun Lake (Switzerland) the concentration of PBDEs ranged from 22.8 to $78.3 \mathrm{pg} / \mathrm{L}$, the predominating congeners being BDE-57 and 209. Similar amounts were registered in the Kander River flowing into the lake [14]. In Lake Ontario (Canada) the total concentration of PBDEs varied from 4 to $13 \mathrm{pg} / \mathrm{L}$, the predominating formulations being BDE-47 and 99 [56]. In Lake Michigan the concentration of $\Sigma$ PBDEs rose from $31 \mathrm{pg} / \mathrm{L}$ in 1997 to $158 \mathrm{pg} / \mathrm{L}$ in 2003 [57]. The PBDE concentration determined in the San Francisco estuary was 513 pg/L [58], with the predominating congeners BDE-209, 47, 99. In the Predecelle River in the suburbs of Paris the concentration of PBDEs ranged from 2.3 to $2.7 \mathrm{ng} / \mathrm{L}$, while the level of BDE-209 was 2.1 to $2.48 \mathrm{ng} / \mathrm{L}$ [39]. In the Aire River (UK) flowing mainly through industrial regions the concentration of BDE-209 varied from 17 to $295 \mathrm{ng} / \mathrm{L}$ [51]. In surface waters in regions with a well-developed electronics industry the concentrations of $\Sigma$ PBDEs were $22.4 \mathrm{ng} / \mathrm{L}$, including BDE-209 in the amount of $7.3 \mathrm{ng} / \mathrm{L}$. These levels were higher than in highly industrialized areas within the same 
geographic region in China, where the concentration of ¿PBDEs was $18.9 \mathrm{ng} / \mathrm{L}$, the concentration of BDE-209 being $7.3 \mathrm{ng} / \mathrm{L}$ [49].

As regards the contamination of ground waters with PBDEs, the major concern is exposed geological features. In the aquifer in eastern Ontario (Canada) the maximal concentration level of $\Sigma$ PBDEs was $94 \mathrm{ng} / \mathrm{L}$ (the average value being $12.6 \mathrm{ng} / \mathrm{L}$ ). Slightly higher concentrations were determined in all positive samples collected in the summer. Infiltration of atmospheric precipitation may have caused the reduction of $\Sigma$ PBDEs, or it may be attributed to seasonal variations of PBDE concentrations in atmospheric air. The highest concentrations were found for BDE-209, 47, and 99 (Fig. 1). The strong correlation of PBDE levels with concentrations of nitrogen compounds and the analysis of the land development features indicate that potential sources of PBDE contamination are cesspools, organic fertilizers and deposition of airborne substances [41].

\section{Soils and Aquatic Sediments}

The receptors of man-made organic pollutants are commonly soils and sediments on the bottoms of rives and water reservoirs. Typically, PBDE concentrations in soils are of the order of several ng/g. In soils near Bratislava the concentrations of $\Sigma$ PBDEs ranged from 0.087 to $0.627 \mathrm{ng} / \mathrm{g}$ [54]. In rural areas and woodlands in UK and Norway, the concentrations of $\Sigma$ PBDEs ranged from 0.065 to $12 \mathrm{ng} / \mathrm{g}$ [59].

On a local scale the increase in the PBDE levels was detected in flooded areas and in agricultural regions (up to several hundred $\mathrm{ng} / \mathrm{n}$ ), where the sewage sludge is used [45, $60]$ or where the land is irrigated with treated effluents [36].

Concentrations of $\Sigma$ PBDEs in woodlands in the Guiyi region (China) ranged from 2.0 to $6.22 \mathrm{ng} / \mathrm{g}$, the proportion of BDE-209 being $63-81 \%$. In the rice fields the levels were $45.1-102 \mathrm{ng} / \mathrm{g}$ and in the vicinity of the dumping site of dismantled and incinerated electronic devices they ranged from 85.0 to $201.0 \mathrm{ng} / \mathrm{g}$. At the incineration and dumping site the concentration of $\mathrm{PPBDEs}$ varied from 2906 to $44473 \mathrm{ng} / \mathrm{g}$ [61]. In soils in agricultural regions the concentration of $\Sigma$ PBDEs varied from $2.96 \mathrm{ng} / \mathrm{g}$ to 200 $\mathrm{ng} / \mathrm{g}$, the predominant congener being BDE-209 [18].

Bottom sediments are a vital component of the aquatic ecosystem, used in monitoring surface water quality [62, 63]. PBDE concentrations in bottom sediments are typically higher than in soils. For example, the $\Sigma$ PBDE concentrations determined in rivers are: from 0.29 to 10.4 in the Danube River (Austria) [64] and from $1.0 \mathrm{ng} / \mathrm{g}$ to 281.1 $\mathrm{ng} / \mathrm{g}$ in Czech rivers [49]. The concentration of PBDEs (excluding BDE 209) determined in the estuary of the Vistula River in Poland was $0.2 \pm 0.1 \mathrm{ng} / \mathrm{g}$ [65]. PBDE concentrations tend to increase gradually over the river course and as the rivers flow into industrial regions. Concentrations registered below the local pollution sources are higher by several orders of magnitude. In the bottom sediments of the Lusatian Neisse River (The Czech Republic) the concentrations of $\Sigma$ PBDEs downstream from the carpet manufacturing factory was $490 \mathrm{ng} / \mathrm{g}$ and the level of $328 \mathrm{ng} / \mathrm{g}$ was registered downstream from the hazardous waste incineration plant [53]. The concentration of $\mathrm{PBDE}$ in the sample collected from the Vero River (Spain) $5 \mathrm{~m}$ below the industrial park was $14,395 \mathrm{ng} / \mathrm{g}$ and one kilometre further $-5,531 \mathrm{ng} / \mathrm{g}$ [66].

Lake sediments and peat bogs are "natural archives" of long-term changes in the quality of the natural environment on a local and regional scale [67]. The concentrations of $\Sigma$ PBDEs in the sediments of Lake Mjosa (Norway) ranged from 0.6 to $27 \mathrm{ng} / \mathrm{g}$ [68], in Lake Thun (Switzerland): from 0.1 to $5.1 \mathrm{ng} / \mathrm{g}$ [14], in Lake Maggiore (Italy): from 1.6 to $18.6 \mathrm{ng} / \mathrm{g}$ [69]. In most cases the predominant congener was BDE-209, accounting for $50 \%-90 \%$ of the total amount. Deca-BDE concentration in Lake Thun and Greifen increased over the years 1980-2000 [14]. The 5 PBDE concentration (excluding BDE 209) in the bottom sediments in the southern part of the Baltic Sea (off the Polish coast) ranged from $2.41 \pm 0.78 \mathrm{ng} / \mathrm{g}$ to $6.22 \pm 1.26 \mathrm{ng} / \mathrm{g}$ [70].

Highly variable and extremely high concentrations were determined in bottom sediments in rivers in the Shenhen region (China). The lowest levels of $\Sigma$ PBDEs (excluding BDE 209) registered in the region were in the range from 0.18 to $26.5 \mathrm{ng} / \mathrm{g}$. In rural areas the concentrations ranged from 2.08 to $169 \mathrm{ng} / \mathrm{g}$, in urban areas from 10.1 to 2212 $\mathrm{ng} / \mathrm{g}$. In the region dominated by electronic industry the concentration of $\Sigma$ PBDEs (excluding BDE-209) ranged from 1,528 to $49,000 \mathrm{ng} / \mathrm{g}$. The maximal concentration of BDE209 in rural areas was $680 \mathrm{ng} / \mathrm{g}$, in urban areas 2,673 ng/g, and in the areas where the electronics industry is located $135,000 \mathrm{ng} / \mathrm{g}$ [52]. These amounts correspond to the range of PBDE concentrations in the floor dust in the electronic equipment dismantling plants, where 5 PBDE levels ranged from 1960 to $340,710 \mathrm{ng} / \mathrm{g}$, including BDE-209, whose amounts vary between 910 and 320,400 ng/g [71].

\section{PBDEs in Surface Waters of Poland}

The relevant regulation [72] specifies the admissible level to be $0.5 \mathrm{ng} / \mathrm{L}$ of PBDEs as the year-average concentration in homogeneous waters and $0.2 \mathrm{ng} / \mathrm{L}$ for homogeneous parts of coastal and flowing waters. It is assumed that the year-average values provide a certain safety margin to protect from short-term increases in PBDE concentrations during the regular discharges, while the admissible maximal concentrations are equal to year-average values. The environmental quality standard specifies the sum of concentrations of congeners 28, 47, 99, 100, 153, and 154 contained in penta-PBDE as a product.

PBDE concentrations determined in surface waters in Podlasie Province were: $<0.1 \mathrm{ng} / \mathrm{L}$ and $<0.05 \mathrm{ng} / \mathrm{L}[73]$ The $\Sigma$ PBDE concentrations in rivers and lakes in Zachodniopomorskie Province does not exceed the levels set forth in relevant standards. Significant amounts (about 1 $\mu \mathrm{g} / \mathrm{L}$ ) were registered in transitional and coastal waters in the province, for example in the estuaries of the Dziwna and Świna rivers, in Kamieński Lagoon, and in coastal rivers [74]. The exceeded admissible levels of $\Sigma$ PBDEs were not included in the assessments chiefly because the determinations were too scarce [75]. The relationship was 
established between the PBDE concentrations and those of total nitrogen (Fig. 3) and fluoranthene (Fig. 4).

Determining PBDE concentrations (and other organic pollutants) has been included in the National Environmental Monitoring program for 2013-15. The concentrations shall be determined at select points among several hundred locations included in the basic program [76].

\section{Conclusion}

The factors responsible for PBDE presence in the environment are manufacturing and disposal of products containing PBDEs. Major differences between PBDE concentrations determined in the environment are associated with land development levels, which is best illustrated by the

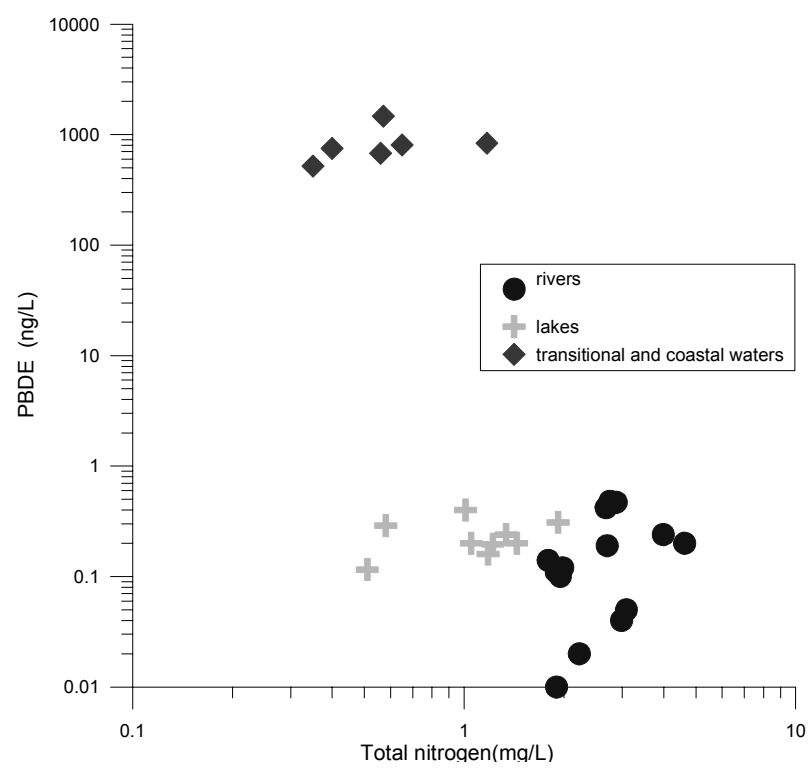

Fig. 3. $\Sigma$ PBDEs vs. total nitrogen in surface waters in Zachodniopomorskie Province [74].

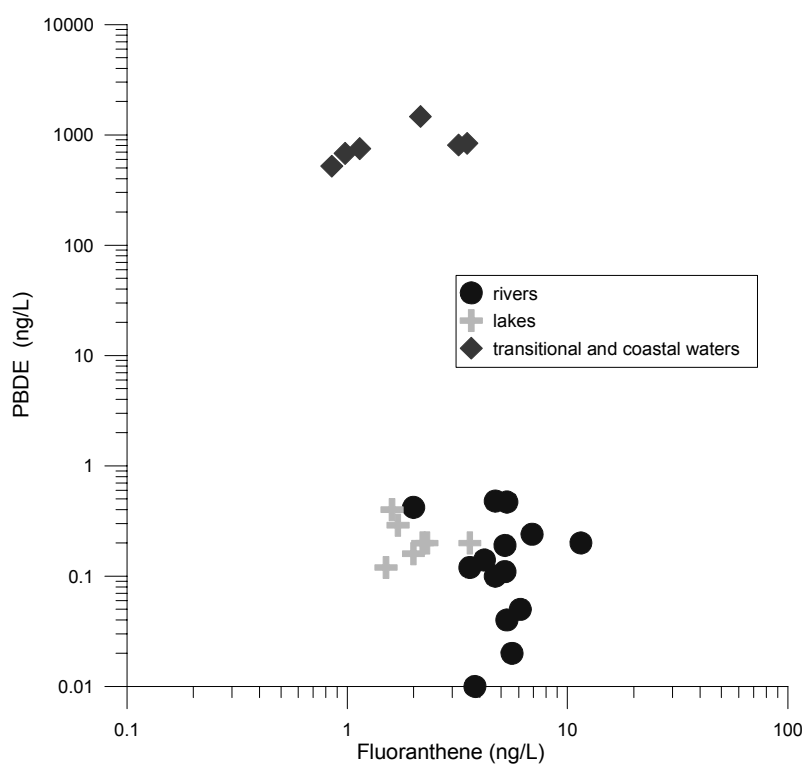

Fig. 4. $\Sigma$ PBDEs vs. fluoranthene in surface water in Zachodniopomorskie Province [74]. example of China. No restrictions imposed upon the use of PBDEs and the largest market of imports and recycling of electronic goods world-wide pose a major threat to the natural environment. This condition is revealed by elevated PBDE concentrations in various ecosystems in relation to other world regions $[18,19,52]$.

PBDEs leak to surface and ground waters with discharges from wastewater treatment plants and through wet and dry deposition. Still higher concentrations were detected in rivers in industrial regions $[39,51]$. PBDE concentrations in river sediments tend to increase gradually over the river course and when flowing through industrial regions. $[53,66]$. Apart from areas affected by local emission sources, long-range atmospheric transport of pollutants and atmospheric deposition are the main sources of their occurrence. PBDEs can be atmospherically transported over long distances and even to high mountain regions. PBDEs can also leak to local water intakes, threatening the areas at some distance from the source of pollution [21].

Due to the scarcity of information about PBDE concentrations in ground waters, this problem has not yet been fully investigated. It is reasonable to suppose that, similar to other anthropogenic contamination, the problem will be most acute in unconfined aquifers [41], particularly those in exposed geological formations in urban areas.

The amounts of detected PBDEs in the environment are now higher than in previous years and the effects of bans restricting the use of PBDEs are now becoming apparent. PBDE deposition is estimated based on the samples of the firn core in the alpine region in 2003-07 is found to be lower than in the years 1997-2001 [21]. The increasing mass of electronic waste is still the main source of PBDE emissions, even though their actual content is rather low $(<0.1 \%)$.

The presence of deca-PBDE (BDE-209) being its main component also poses a threat to the environment, as illustrated by research data summarized in this text. In the process of debromination, deca-PBDE becomes a source of lighter yet more persistent congeners.

As regards the amounts of PBDEs in the aquatic environment (Fig. 1), it is reasonable to expect that the admissible limits specified in the relevant Regulation can be exceeded. In Polish conditions the threat to the water ecosystem seems real. However, the current status of research in this field is still insufficient to allow a reliable assessment of the scale of the problem.

Because of its persistent character and short-time (in terms of geology) presence in the environment (manufacturing began after 1965) and industrial origins, PBDE levels have become a reliable anthropogenic indicator of environment quality in the last four decades.

\section{Acknowledgements}

The author wishes to thank Prof. S. Witczak for his suggestions and the reviewer for valuable comments. The research work was supported under the AGH University of Science and Technology Research Programs, No. 11.11.190.555. 


\section{References}

1. PAWŁOWSKI L. Role of environment al monitoring in implementation of sustainable development. Annual Set The Environment Protection. 13, 333, 2011 [In Polish with English abstract].

2. Journal of Laws No. 258, item 1550 of $15^{\text {th }}$ November 2011 [In Polish].

3. KUŁAKOWSKI P. Priority and hazardous substances in water environment. Results of analytical methods implementation on the base of the research being carried out within the framework of the project p10302 Tarnów pp. 139, 2009.

http://www.wios.tarnow.pl/p10302/rezultaty/1_priority_ and_hazadrous_substances.pdf [9.06.2014].

4. Stockholm Convention on Persistent Organic Pollutants www.pops.int) [9. 06. 2006].

5. VONDERHEIDE A., MUELLER K., MEIJA J., WELSH G. Polybrominated diphenyl ethers: causes for concern and knowledge gaps regarding environmental distribution, fate and toxicity. Sci. Total Environ., 400, 425, 2008.

6. LAW R., ALLCHIN C., DE BOER J., COVACI A., HERZKE D., LEPOM P., MORRIS S., TRONCZYNSKI J., DE WIT C. Levels and trends of brominated retardants in the European environment. Chemosphere 64, 187, 2006.

7. Journal of Laws of the Republic of Poland item 547 of $8^{\text {th }}$ May 2013 [In Polish].

8. NI K., LU Y., WANG T., SHI Y., KANNAN K., XU L., LI Q., LIU S. Polybrominated diphenyl ethers (PBDEs) in China: Policies and recommendations for sound management of plastic from electronic wastes. J. Environ. Manage., 115, 114, 2013.

9. WHO (World Health Organization),. Environmental Health Criteria 162, Brominated Diphenyl Ethers. 1994.

10. PETREAS M., OROS D. Polybrominated diphenyl ethers in California wastestreams, Chemosphere 74, 996, 2009.

11. TER SCHURE A., LARSSON P., AGRELL C., BOON J.P. Atmospheric transport of polybrominated diphenyl ethers and polychlorinated biphenyls to the Baltic Sea. Environ. Sci. Technol. 38, 1282, 2004.

12. SU Y., HUNG H., SVERKO E., FELLIN P., LI H. Multiyear measurements of polybrominated diphenyl ethers (PBDEs) in the Arctic atmosphere. Atmos. Environ. 41, 8725, 2007.

13. HARRAD S., HUNTER S. Concentrations of polybrominated diphenyl ethers in air and soil on a rural-urban transect across a major UK conurbation. Environ. Sci. Technol. 40, 4548, 2006

14. BOGDAL C., SCHERINGER M., SCHMID P., BLÄUENSTEIN M., KOHLER M., HUNGERBÜHLER $\mathrm{K}$. Levels, fluxes and time trends of persistent organic pollutants in Lake Thun, Switzerland: Combining trace analysis and multimedia modeling, Sci. Total Environ. 408, (2010), 3654, 2010.

15. HOH E., HITES R.A. Brominated flame retardants in the atmosphere of the east-central United States. Environ. Sci. Technol. 39, 7794, 2005.

16. WANG C., LI W., CHEN J., WANG H., LI T., SHEN G, SHEN H., HUANG Y., WANG R., WANG B, ZHANG Y., TANG J., LIU W., WANG X., TAO S. Summer atmospheric polybrominated diphenyl ethers in urban and rural areas of northern China. Environ. Pollut. 171, 234, 2012.

17. MARTELLINI T., JONES K., SWEETMAN A., GIANNONI M., PIERI F., CINCINELLI A. The contribution of waste water treatment plants to PBDEs in ambient air. Environ. Pollut. 169, 242, 2012.

18. DONG Y., LI L., BIE P., JIA S., WANG Q., HUANG Z., QIU X., ZHANG J., HU J. Polybrominated diphenyl ethers in farm land soils: Source characterization, deposition cintribution and apportionment. Sci. Total Environ. 466-467, 524, 2014

19. WONG M., WU S., DENG W., YU X., LUO Q., LEUNG A., WONG C. LINKSEMBURG W., WONG A. Export of toxic chemicals - A review of the case of uncontrolled electronic-waste recycling. Environ. Pollut., 149, (2), 131, 2007.

20. TER SCHURE A., LARSSON P. Polybrominated diphenyl ethers in precipitation in Southern Sweden (Skåne, Lund). Atmos. Environ. 36, 4015, 2002.

21. KIRCHGEORG T., DREYER A., GABRIELI J., KEHRWALD N., SIGL M., SCHWIKOWSKI M., BOUTRON C., GAMBARO A., BARBANTE C., EBINGHAUS R. Temporal variations of perfluoroalkyl substances and polybrominated diphenyl ethers in alpine snow. Environ. Pollut., 178, 367, 2013.

22. MARIANI G., CANUTI E., CASTRO-JIMÉNEZ J., CHRISTOPH E., EISENREICH S, HANKE G., SKEJO H., UMLAUF G. Atmospheric input of POPs into Lake Maggiore (Northern Italy): PBDE concentrations and profile in air, precipitation, settling material and sediments. Chemosphere 73, 114, 2008.

23. MOON H., KANNAN K., LEE S-J., CHOI M. ATMOSPHERIC. Deposition of polybrominated diphenyl ethers (PBDEs) in coastal areas in Korea. Chemosphere 66, 585, 2007.

24. LIN L-F., CHANG K-L., LIOA W-T., LAI Y-C., LEE, Y-Y., WANH L-C., CHANG-CHIEN G-P. Atmosspheric Concentration and Dry Deposition of Polybrominated Diphenyl Ethers in Southern Taiwan. Aerosol Air Qual. Res., 12, 1135, 2012.

25. KWAN C., TAKADA H., MIZUKAWA K., TORII M., KOIKE T., YAMASHITA R., RINAWATI, SAHA M., SANTIAGO E. PBDEs in leachates from municipal solid waste dumping sites in tropical Asian countries: phase distribution and debromination. Environ. Sci. Pollut. R. 20, 4188, 2013.

26. OSAKO M., KIM Y-J., SAKAI S-I. Leaching of brominated flame retardants in leachate from landfills in Japan. Chemosphere 57, 1571, 2004.

27. KOTOWSKA U., BIEGAŃSKA K., VALERY A. ISIDOROV V.A. Screening of trace organic compounds in municipal wastewater by gas chromatography - mass spectrometry, Pol. J. Environ. Stud. 21, (1), 129, 2012.

28. KIM M., GUERRA P., THEOCHARIDES M., BARCLAY K., SMYTH S., ALAEE S. Parameters affecting the occurrence and removal of polybrominated diphenyl ethers in twenty Canadian wastewater treatment plants. Water Res. 47, 2213, 2013.

29. ANDERSON T., MACRAE J. Polybrominated diphenyl ethers in fish and wastewater samples from an area of the Penobscot River in Central Maine. Chemosphere 62, 1153, 2006.

30. VOGELSANG C., GRUNG M., JANTSCH T., TOLLEFSEN K., LILTVED H. Occurrence and removal of selected organic micropollutants at mechanical, chemical and advanced wastewater treatment plants in Norway. Water Res. 40, 3559, 2006.

31. OLIAEI F., KING P., PHILLIPS L. Occurrence and concentration of polybrominated diphenyl ethers (PBDEs) in Minnesota environment. Organohalogen Compounds 58, 185, 2002. 
32. ODUSANYA D., OKONKWO J., BOTHA B. Polybrominated diphenyl ethers (PBDEs) in leachate from selected landfill sites in South Africa. Waste Manage. 29, (1), 96, 2009.

33. DASO A., FATOKI O. ODENDAAL JU., OLUJIMI O. Occurrence of Selected Polybrominated Diphenyl Ethers and 2,20,4,40,5,50-Hexabromobiphenyl (BB-153) in Sewage Sludge and Effluent Samples of a WastewaterTreatment Plant in Cape Town, South Africa. Arch. Environ. Con. Tox. 62, 391, 2012.

34. RICKLUND N., KIERKEGAARD A., MCLACHLAN M. An international survey of decabromodiphenyl ethane (deBDethane) and decabromodiphenyl ether (decaBDE) in sewage sludge samples. Chemosphere 73, 1799, 2008.

35. WANG X., XI B., HUO S., LI D., PAN H., XIA X., ZHANG J, REN, Y., LIU H. Polybrominated diphenyl ethers occurrence in major inflowing rivers of Lake Chaohu (China): Characteristics, potential sources and inputs to lake. Chemosphere 93, 1624, 2013.

36. ZHANG J., TOMANEK M., DONG H., ARNOLD R., ELA W., QUANRUD D., SAES E. Fate of Polubrominated Diphenyl Ethers, Nonylphenol, and Estrogenic Activity during Managed Infiltration of Wastewater Effluent. Journal of Environmental Engineering, 134, 433, 2008.

37. HOPE B., PILLSBURY L., BOLING B. A state-wide survey in Oregon (USA) of trace metals and organic chemicals in municipal effluent. Sci. Total Environ. 417-418, 263, 2012.

38. HOENICKEA R., OROSA D., ORAMA J., TABERSKI K. Adapting an ambient monitoring program to the challenge of managing emerging pollutants in the San Francisco Estuary. Environ. Res. 105, 132, 2007.

39. LABADIE P., TLILI, K., ALLIOT F., BOURGES C., DESPORTES A., CHEVREUIL M. Development of analytical procedures for trace-level determination of polybrominated diphenyl ethers and tetrabromobisphenol A in river water and sediment. Anal. Bioanal. Chem. 396, 865, 2010.

40. MOON H., CHOI M., YU J., JUNG R-H, CHOI H-G. Contamination and potential sources of polybrominated diphenyl ethers (PBDEs) in water and sediment from the artificial Lake Shihwa, Korea. Chemosphere 88, 837, 2012.

41. LEVISON J., NOVAKOWSKI K., REINER E., KOLIC T. Potential of groundwater contamination by polybrominated diphenyl ethers (PBDEs) in a sensitive bedrock aquifer (Canada). Hydrology Journal 20, 401, 2012.

42. FABRELLAS B., LARRAZABAL D., MARTINEZ M.A., ELJARRAT E., BARCELÓ D. Presence of polybrominated diphenyl ethers in Spanish sewage sludges: important contribution of deca-BDE. Organohalogens Compounds 66, 3755, 2004.

43. NORTH K. Tracking polybrominated diphenyl ether releases in a wastewater treatment plant effluent, Palo Alto, CA. Environ. Sci. Technol. 38, 4484, 2004.

44. KNOTH W., MANN W., MEYER R., NEBHUTH J. Polybrominated diphenyl ether in sewage sludge in Germany. Chemosphere 67, 1831, 2007.

45. ELJARRAT E., MARSH G., LABANDEIRA A., BARCELÓ D. Effect of sewage sludges contaminated with polybrominated diphenylethers on agricultural soils. Chemosphere 71, 1079, 2008.

46. KUPPER T., DE ALENCASTRO L., GATSIGAZI R., FURRER R., GRANDJEAN D., TARRADELLAS J. Concentrations and specific loads of brominated flame retardants in sewage sludge. Chemosphere 71, 1173, 2008.
47. NÁPRAWNÍKOWÁ M., PULKRABOVÁ J., HRÁDKOVÁ P., POUSTKA J., HAJŠLOVA J. Levels of PBDEs and PCBs in sediments and sewage sludges collected in several regions of the Czech Republic, Organohalogen Compounds 70, 1829, 2008

48. CINCINELLI A., MARTELLINI T., MISURI L., LANCIOTTI E., SWEETMAN A., LASCHI S., PALCHETTI I. PBDEs in Italian sewage sludge and environmental risk of using sewage sludge for land application. Environ. Pollut. 161, 229, 2012.

49. WANG J., LIN Z., LIN K., WANG C., ZHANG W., CUI C., LIN J., DONG Q., HUANG C. Polybrominated diphenyl ethers in water, sediment, soil, and biological samples from different industrial areas in Zhejiang, China. J. Hazard. Mater. 197, 211, 2011

50. ZHAO X., ZHANG H, NI Y., LU X., ZHANG X., SU F., FAN J., GUAN D., CHEN J. Polybrominated diphenyl ethers in sediments of the Daliao River Estuary, China: Levels, distribution and their influencing factors. Chemosphere 82, 1262, 2011.

51. CRISTALE J., KATSOYIANNIS A., SWEETMAN A., JONES K., LACORTE S. Occurrence and risk assessment of organophosphorus and brominated flame retardants in the River Aire (UK). Environ. Pollut. 179, 194, 2013.

52. SUN J-L., CHEN Z-X., NI H-G, ZENG H. PBDEs as indicator chemicals of urbanization along an urban/rural gradient in South China, Chemosphere 99, 471, 2013.

53. HLOUŠKOVÁ V., LANKOVÁ D., KALACHOVÁ K., HRÁDKOVÁ P., POUSTKA J., HAJŠLOVÁ J., PULKRABOVÁ J. Brominated flame retardants and perfluoralkyl substances in sediments from Czech aquatic ecosystem. Sci. Total Environ. 470-471, 407, 2014.

54. THOREZ U., BANDOWE A., SOBOCKA J., WILCKE W. Method optimization to measure polybrominated diphenyl ether (PBDE) concetrations in soils of Bratislava, Slovakia. Environ. Pollut. 158, 2208, 2010.

55. CHEN C., ZHAO H., CHEN J., QIAO X., XIE Q, ZHANG Y. Polybrominated diphenyl ethers in soils of the modern Yellow River Delta, China: occurrence, distribution and inventory. Chemosphere 88, 791, 2012.

56. LUCKEY F., FOWLER B., LITTEN S. Establishing baseline levels of polybrominated diphenyl ethers in Lake Ontario surface waters. 2nd Int. Workshop on Brominated Flame Retardants, Stockholm, Sweden, May 2001, pp. 337-339, 2001.

57. HALE R., ALAEE M., MANCHESTER-NEEVIG J., STAPLETON H., IKONOMOU M. Polybrominated diphenyl ether flame retardants in the North American environment. Environ. Int. 29, 771, 2003.

58. OROS D., HOOVER D., RODIGARI F., CRANE D., SERICANO J. Levels and distribution of polybrominated diphenyl ethers in water, surface sediments, and bivalves from the San Francisco Estuary. Environ. Sci. Technol. 39, 33, 2005.

59. HASSANIN A., BREIVIK K., MEIJER S., STEINNES E., THOMAS G., JONES K. PBDEs in European background soils: levels and factors controlling their distribution. Environ. Sci. Technol 38, 738, 2004.

60. SELLSTRÖM U., DE WIT C., LUNDGREN N., TYSKLIND M. Effect of sewage-sludge application on concentrations of higher-brominated diphenyl ethers in soils and earthworms. Environ. Sci. Technol. 39, 9064, 2005.

61. WONG M., WU S., DENG W., YU X., LUO Q., LEUNG A., WONG C. LINKSEMBURG W., WONG A. Export of toxic chemicals $-\mathrm{A}$ review of the case of uncontrolled electronic-waste recycling. Environ. Pollut., 149, (2), 131, 2007. 
62. KASPEREK R., ROSIK-DULEWSKA C., WIATKOWSKI M. Studies of bottom sediments in the border meanders of upper Odra river. Annual Set the Environment Protection), 9, 293, 2007 [In Polish with English abstract].

63. IBRAGIMOW A. WALNA B., SIEPAK M. Effects of Flooding on the Contamination of Floodplain Sediments with Available Fractions of Trace Metals (Western Poland), Pol. J. Environ. Stud. 22, (1), 131, 2013.

64. MOCHE W., STEPHAN K. Levels of PBDE in various environmental matrices in Austria. Organohalogen Compounds. 61, 147, 2003.

65. WASZAK I., DABROWSKA H., KOMAR-SZYMCZAK $\mathrm{K}$. Comparison of common persistent organic pollutants (POPs) in flounder (Platichthys flesus) from the Vistula (Poland) and Douro (Portugal) River estuaries, Mar. Pollut. Bull. 81, 225, 2014.

66. ELJARRAT E., LABANDEIRA A., MARSH G. RALDÚA D., BARCELÓ D. Decabrominated diphenyl ether in river fish and sediment samples collected downstream an industrial park. Chemosphere 69, 1278, 2007.

67. KABAŁA C., BOJKO O. Trends in trace element concentrations in holocene bottom sediments of a Lake Wielki Staw in the Karkonosze Mountains. Pol. J. Environ. Stud. 23, (2), 357, 2014.

68. SCHLABACH M., FJELD E., GUNDERSEN H., MARIUSSEN E., KJELLBERG G., BREIVIK E. Pollution of Lake Mjøsa by brominated flame retardants. Organohalogen Compounds 66, 3779, 2004.

69. GUZZELLA L., ROSCIOLI C., BINELLI A. Contamination by polybrominated diphenyl ethers of sedi- ments from the Lake Maggiore basin (Italy and Switzerland). Chemosphere 73, 1684, 2008.

70. WASZAK I., DABROWSKA H., GÓRA A. Bioaccumulation of polybrominated diphenyl ethers (PBDEs) in flounder (Platichthys flesus) in the southern Baltic Sea, Mar. Environ. Res. 79, 132, 2012.

71. LI Y., DUAN Y-P., HUANG F., XIANG N., MENG X-Z, CHEN L. Polybrominated diphenyl ethers in e-waste: Level and transfer in a typical e-waste recycling site in Shanghai, Easter China. Waste Manage. 34, 1059, 2014.

72. Journal of Laws No 257, item 1545 of $9^{\text {th }}$ November 2011 [In Polish].

73. Tabulated data for assessment of quality and chemical composition of waters in rivers are available in JWC Assessment for 2010-2012 [In Polish]. http://www.wios.bialystok.pl?go=pub

74. Assessment of quality of surface waters in the Zachodniopomorskie Province for 2010-2012 [In Polish] http://www.geopomerania.pl/ocena-jakoci-wod/117-ocenajakoci-wod-powierzchniowych-w-wojewodztwiezachodniopomorskim-w-latach-2010-2012.

75. Assessment of water in the Zachodniopomorskie Province [in Polish] http://www.wios.szczecin.pl/bip/files/4780126ACCBB4B 60B164E13E30BFA5A7/Ocena $\% 20$ stanu $\% 20 w \% C 3 \% B 3 d$. pdf

76. The state environmental monitoring program for the year 2013-2015, Warszawa 2012 [In Polish]. http://www.krakow.pios.gov.pl/publikacje/2013/ppms 2013_2015.pdf 
